OPEN ACCESS

Edited by:

Rolando Cimaz,

University of Milan, Italy

Reviewed by:

Sezgin Sahin,

Istanbul University-Cerrahpasa, Turkey

Eric Jeziorski,

Center Hospitalier Universitaire de Montpellier, France

*Correspondence:

Diana van Stijn

d.vanstijn@amsterdamumc.n

Specialty section:

This article was submitted to

Pediatric Rheumatology,

a section of the journal

Frontiers in Pediatrics

Received: 10 November 2020 Accepted: 21 December 2020

Published: 21 January 2021

Citation:

van Stijn D, Slegers A, Zaaijer $H$ and Kuijpers T (2021) Lower CMV and

EBV Exposure in Children With

Kawasaki Disease Suggests an

Under-Challenged Immune System.

Front. Pediatr. 8:627957.

doi: 10.3389/fped.2020.627957

\section{Lower CMV and EBV Exposure in Children With Kawasaki Disease Suggests an Under-Challenged Immune System}

\author{
Diana van Stijn ${ }^{1 *}$, Annemarie Slegers ${ }^{1}$, Hans Zaaijer $^{2}$ and Taco Kuijpers ${ }^{1}$ \\ ${ }^{1}$ Department of Pediatric Immunology, Rheumatology and Infectious Diseases, Emma Children's Hospital, Amsterdam \\ University Medical Center, University of Amsterdam, Amsterdam, Netherlands, ${ }^{2}$ Laboratory of Clinical Virology, Department \\ of Medical Microbiology, Center for Infection and Immunity Amsterdam University Medical Center, University of Amsterdam, \\ Amsterdam, Netherlands
}

Background: Kawasaki Disease $(K D)$ is a pediatric vasculitis of which the pathogenesis is unclear. The hypothesis is that genetically pre-disposed children develop KD when they encounter a pathogen which remains most often unidentified or pathogen derived factors. Since age is a dominant factor, prior immune status in children could influence their reactivity and hence the acquisition of $\mathrm{KD}$. We hypothesized that systemic immune responses early in life could protect against developing KD. With this study we tested whether the incidence of previous systemic cytomegalovirus (CMV) or Epstein-Barr virus (EBV) infection is lower in children with KD compared to healthy age-matched controls.

Methods and Results: We compared $86 \mathrm{KD}$ patients with an age-matched control group regarding CMV and EBV VCA IgG measurements (taken before or 9 months after IVIG treatment). We found that both CMV and EBV had an almost 2-fold lower seroprevalence in the KD population than in the control group.

Conclusions: We suggest that an under-challenged immune system causes an altered immune reactivity which may affect the response to a pathological trigger causing KD in susceptible children.

Keywords: Kawasaki disease, Epstein-Barr virus, immune system, viral exposure, cytomegalovirus

\section{INTRODUCTION}

Kawasaki disease $(\mathrm{KD})$ is a rare pediatric vasculitis of unknown etiology that can lead to coronary artery aneurysms (CAAs). These CAAs can result in cardiac complications (1) and even be fatal when an occlusion occurs due to secondary complications such as thrombosis or stenosis (2). If treated properly, i.e., preferably within the first 10 days of illness with intravenous immunoglobulin (IVIG) and oral aspirin for a prolonged period of time, a decrease in the incidence of CAAs has been reported $(3,4)$. However, with this treatment still $\sim 2.4-27.8 \%$ of the KD patients develop CAAs (5-11). To further prevent the development of CAAs due to $\mathrm{KD}$, we need more understanding of the etiology of the disease. Multiple studies suggest that both infectious and genetic factors are involved (12-14). Most likely KD is triggered in genetically pre-disposed children by an intracellular pathogen (15). Several genes have been identified to be associated with KD in children (e.g., ITPKC, CASP3, CD40, and FCGR2A) (16-30). Possible genetic contribution 
to the development of CAAs and the presence of so-called therapy or IVIG resistance is also a topic of research (30-40).

Over the past decades research also aimed to find a singular ubiquitous pathogen, that could trigger the immune system in genetically pre-disposed children. The hypothesis of an infectious pathogen is supported by the epidemiologic features of $\mathrm{KD}$, namely that young infants under the age of 6 months and adults very rarely develop $\operatorname{KD}(12,41,42)$. Young infants are protected by maternal antibodies, and adults already would have been exposed to this pathogen and protected by the adaptive immune system. Moreover, sudden peaks in incidence as observed in Japan, support such singular transmissible agents to evoke KD $(43,44)$. The current COVID-19 pandemic (caused by coronavirus SARS-Cov-2) also suggests that an infectious agent can, at least in some of the affected children, cause a syndrome similar or even identical with $\mathrm{KD}$ or KD-like shock syndrome (45-48). Despite extensive research, a common pathogen as the cause of KD has not been identified and a variety of pathogens have been found in KD patients in the past such as SARSCoV-2, measles, human herpesvirus-6, parvovirus B19 and EBV $(45,49-55)$. Most likely the immune response causing KD can be triggered by multiple pathogens, as opposed to one single and specific pathogen.

Studies have suggested that the immune response in $\mathrm{KD}$ is mainly IgA-driven with a notable absence of IgM and IgG at the affected sites $(41,56,57)$. Also high concentrations of IgA have been found at mucosal sites of the trachea of KD patients (56). These findings suggest that the upper respiratory tract could be the point of access for the pathogen to enter the body and consequently triggering $\mathrm{KD}$, which may be associated with the local enlargement of often unilateral lymph nodes in the sternocleidomastoideus region. Studies relating wind patterns to the spread of KD further support the suggestion of an airborne factor $(58,59)$. The higher prevalence of $\mathrm{KD}$ among Japanese, Taiwanese and children from South-East Asia as well as the familial cases and incidence among identical twins suggest a genetic risk, which suggest that an infectious trigger causes KD in genetically susceptible individuals. The genetic impact and its contribution to the risk to develop $\mathrm{KD}$ seems limited since the disease is particularly prevalent under the age of 5 (11). This suggests that development of immune reactivity plays an important role in the inherent susceptibility to the often undefined KD triggers.

An under-challenged immune system at an early age has previously been proven to pre-dispose children to specific diseases such as Acute Lymphoblastic Leukemia (60). This abnormal response to a common infection due to an underchallenged immune system has become known as the "Greaves" hypothesis $(61,62)$. According to this theory, a low exposure to common infections at a young age, could influence the development of the immune system and result in an altered development and maturation of the adaptive immune system. This would suggest that in the case of $\mathrm{KD}$, not only nature

Abbreviations: CAAs, Coronary artery aneurysms; CMV, cytomegalovirus; EBV, Epstein-Barr virus; HSV, herpes simplex virus; IVIG, intravenous immunoglobulin; KD, Kawasaki disease; VZV, varicella-zoster virus. (genetic factor) plays an important role in the pre-disposition of KD but also nurture (degree of exposure to common infections or environmental immune-reactive substances due to e.g., hygiene measures or living conditions) could play an important role to develop the disease at early age. A low exposure could facilitate a pathological response to a pathogen and triggering $\mathrm{KD}$.

Cytomegalovirus (CMV) and Epstein-Barr virus (EBV) are both highly contagious viruses, which are commonly acquired during early childhood, and remain systemically suppressed in healthy individuals but ever-present, hence shaping or imprinting the immune reactivity of a given individual (63). CMV and EBV are a good reflection of viral exposure, as they spread through bodily fluids, as other commonly acquired viruses do (such as influenza, parvovirus etc.). Therefore, we used CMV and EBV as an indicator of the exposure state to systemic pathogens, reasoning that ever-present viruses would be beneficial to prepare the immune reactivity to subsequent infections. The aim of this study was to assess whether the incidence of CMV and EBV infection is lower in children with $\mathrm{KD}$ compared to a control pediatric population as a potential read-out for the under-challenged state of the immune system in those children affected by KD.

\section{MATERIALS AND METHODS}

\section{Patient Population}

Based on the criteria of the American Heart Association (AHA) (64), patients with KD from the Dutch national referral center for $\mathrm{KD}$ were included. Retrospectively, we collected CMV and EBV antibody test results [IgG to EBNA (Epstein Barr nuclear antigen), IgG and IgM to EBV VCA (viral capsid antigen), and IgG and IgM to CMV] during follow up. After we excluded the patients with positive IgM to exclude any acute infections and the risk of cross-reactive serology results of EBV and CMV, we calculated seroprevalence. Clinical information was extracted from medical records. The blood samples taken within 9 months of IVIG treatment (or 10 months in case of a second IVIG treatment within a month of first treatment) were excluded. Samples taken later than 2 years after onset of disease and patients that were treated for a second episode of $\mathrm{KD}$ were excluded. Samples taken at the time of diagnosis, prior to IVIG infusion were included. We categorized the results according to age and we defined the following age groups: $0.5-2$ years, 2-4 years, 4-6 years, $6-10$ years, and $10-18$ years.

\section{Control Group}

We compared the age-dependent CMV-and EBV-seroprevalence in our $\mathrm{KD}$ patients to $\mathrm{CMV}$ - and EBV-seroprevalences in a control group. For this control group we used the requested EBV VCA IgG and IgM, as well as CMV IgG and IgM results (in the age group 6 months until 18 years) from the same laboratory as the one used by the national referral center from January 2000 until June 2019. As our hospital is a national referral center for $\mathrm{KD}$, the follow-up of KD patients takes place exclusively within our KD team, therefore we were able to exclude $\mathrm{KD}$ patients from the control group by simply disqualifying the EBV VCA IgG and CMV IgG requested by our KD team members (physicians 
TABLE 1 | Age-matched lgG seropositivity for CMV (and/or EBV anti-VCA) in KD cases vs. controls.

\begin{tabular}{|c|c|c|c|c|c|c|c|c|c|c|c|c|c|c|c|}
\hline \multirow{3}{*}{$\begin{array}{l}\text { Age at time of } \\
\text { measurement (years) }\end{array}$} & \multicolumn{5}{|c|}{$\mathrm{CMV}_{+}$} & \multicolumn{5}{|c|}{ EBV+ } & \multicolumn{5}{|c|}{ Both EBV+ and CMV+ at sampling } \\
\hline & \multicolumn{2}{|c|}{ KD } & \multicolumn{2}{|c|}{ No KD } & \multirow[t]{2}{*}{$P$ - value } & \multicolumn{2}{|c|}{ KD } & \multicolumn{2}{|c|}{ No KD } & \multirow[t]{2}{*}{$P$-value } & \multicolumn{2}{|c|}{ KD } & \multicolumn{2}{|c|}{ No KD } & \multirow[t]{2}{*}{$P$-value } \\
\hline & $n$ & $\%$ & $n$ & $\%$ & & $n$ & $\%$ & $n$ & $\%$ & & $n$ & $\%$ & $n$ & $\%$ & \\
\hline $0.5-2$ & $1 / 15$ & 6.7 & 259/716 & 36.2 & 0.018 & $2 / 14$ & 14.3 & 190/679 & 28.0 & 0.257 & $0 / 12$ & 0.0 & $59 / 476$ & 12.4 & $0.193^{*}$ \\
\hline $2-4$ & $6 / 28$ & 21.4 & $322 / 877$ & 36.7 & 0.098 & $6 / 29$ & 20.7 & $410 / 934$ & 43.9 & 0.013 & $4 / 27$ & 14.8 & $142 / 691$ & 20.5 & $0.468^{\star}$ \\
\hline $4-6$ & $5 / 19$ & 26.3 & $279 / 796$ & 35.1 & 0.430 & $3 / 17$ & 17.6 & $495 / 954$ & 51.9 & 0.005 & $1 / 17$ & 5.9 & $146 / 644$ & 22.7 & 0.100 \\
\hline $6-10$ & $5 / 15$ & 33.3 & 492/1202 & 40.9 & $0.552^{\star}$ & $4 / 16$ & 25.0 & $840 / 1406$ & 59.7 & 0.005 & $1 / 15$ & 6.7 & $275 / 986$ & 28.4 & 0.063 \\
\hline
\end{tabular}

${ }^{*}$ Not enough power.

treating KD patients). We also excluded children from the control group with a positive IgM for CMV and/or EBV. Only the first requested CMV and EBV sample of a patient was included. If a laboratory result turned out to be inconclusive (borderline value or not enough blood drawn) this result was excluded, and a possible subsequent value was included instead. "Weak positive" results were regarded as positive. Finally we categorized the results according to age in the same categories as the KD group.

\section{Laboratory Analysis}

Following the instructions of the manufacturers, IgG antibodies to EBV initially were determined using the anti-EBV VCA IgG, and EBNA IgG ELISAs from Biotest/BioRad Medical Diagnostics $\mathrm{GmbH}$ (Dreieich, Germany); later using the automated Liaison assays from DiaSorin (Saluggia, Italy); IgG to CMV initially was determined using the automated AxSym assays from Abbott Diagnostics (Chicago, USA); later using the automated Liaison assays from DiaSorin (Saluggia, Italy).

\section{Statistical Analysis}

Our data consisted of a small sample size with a binomial distribution, therefore we performed a chi-squared test of independence using IBM Corp. Released 2016 SPSS Statistics for Windows, Version 24.0 to compare the seroprevalences in the Kawasaki group with their age- peers in the control group.

\section{RESULTS}

As shown in Table 1, the prevalence of CMV IgG was $6.7 \%$ in the $\mathrm{KD}$ group as compared to $36.2 \%$ in the control group in the $0.5-2$ years age category; $21.4 \%$ compared to $36.7 \%$ in the $2-4$ years old category; $26.3 \%$ compared to $35.1 \%$ in the $4-6$ age group and $33.3 \%$ compared to $40.9 \%$ in the $6-10$ years old category. $P$ values were $0.018,0.098,0.430$, and 0.552 , respectively. Similarly we found a lower prevalence of EBV VCA IgG in the KD group as compared to the control group i.e., $14.3 \%$ as compared to $28.0 \%$ in the age category $0.5-2$ years; $20.7 \%$ compared to $43.9 \%$ in the 2-4 years old category; $17.6 \%$ compared to $51.9 \%$ in the $4-6$ years old category and $25.0 \%$ compared to $59.7 \%$ in the $6-10$ years old category. $P$-values were $0.257,0,013,0.005$, and 0.005 , respectively. When combined we also found a lower seroprevalence of $\mathrm{CMV}$ and $\mathrm{EBV}$ together, in the $\mathrm{KD}$ group compared to the control group, but these differences did not reach levels of statistical significance.

From the $855 \mathrm{KD}$ patients in our database 585 patients had CMV IgG and 586 patients had EBV VCA IgG determined during follow-up. From these patients, 86 patients had CMV IgG and another 86 patients had EBV VCA IgG determined within our chosen timeframe (Figure 1). The majority of the CMV IgGtested $\mathrm{KD}$ patients $(67.4 \%)$ was male and $8.1 \%$ had a partially reported Asian ethnicity. Similarly the majority of the EBV VCA IgG KD tested patients was male $(68.6 \%)$ and $8.1 \%$ had a parental report of a mixed, partial Asian ethnicity (Table 2).

After categorizing the age groups, there was insufficient data of $\mathrm{KD}$ children in the age category of $>10$ years, therefore we did not use this age group for our comparison. In the KD patients with CMV IgG measurements, 12 patients did not receive IVIG and 12 patients in whom IVIG was administered, the CMV IgG measurement took place at diagnosis of KD prior to IVIG (Table 3).

Since we know that seroreactivity after administration of IVIG may last for more than 6-9 months (65) we assessed the median time that had passed between administration of IVIG and the measurement of the seroresponse of CMV IgG in the remaining KD patients which was 14 months (range 0-23) (Table 3). In the KD patients with EBV VCA IgG measurements, 11 patients did not receive IVIG and in 11 patients the EBV VCA IgG measurement took place at KD diagnosis prior to IVIG (Table 3). Also in the remainder of this group the median time that had passed between administration of IVIG and measurement of the seroresponse of EBV VCA IgG was 14 months (range 0-23).

For the control group, a total of 3114 EBV VCA IgG samples and 3591 CMV IgG samples were analyzed by the laboratory of by the national referral center. By comparison, the prevalence of $\mathrm{CMV}$ and $\mathrm{EBV}$ was lower in the $\mathrm{KD}$ population in all age groups tested against their age-matched peers of the control group (Figures $\mathbf{2 A}-\mathbf{C}$ ).

\section{DISCUSSION}

In the KD population, the prevalence of past CMV and EBV infection as indicated by seroprevalence, is lower than in an age-matched control group. This suggests that prior exposure to systemic infections by common viruses such as CMV and 


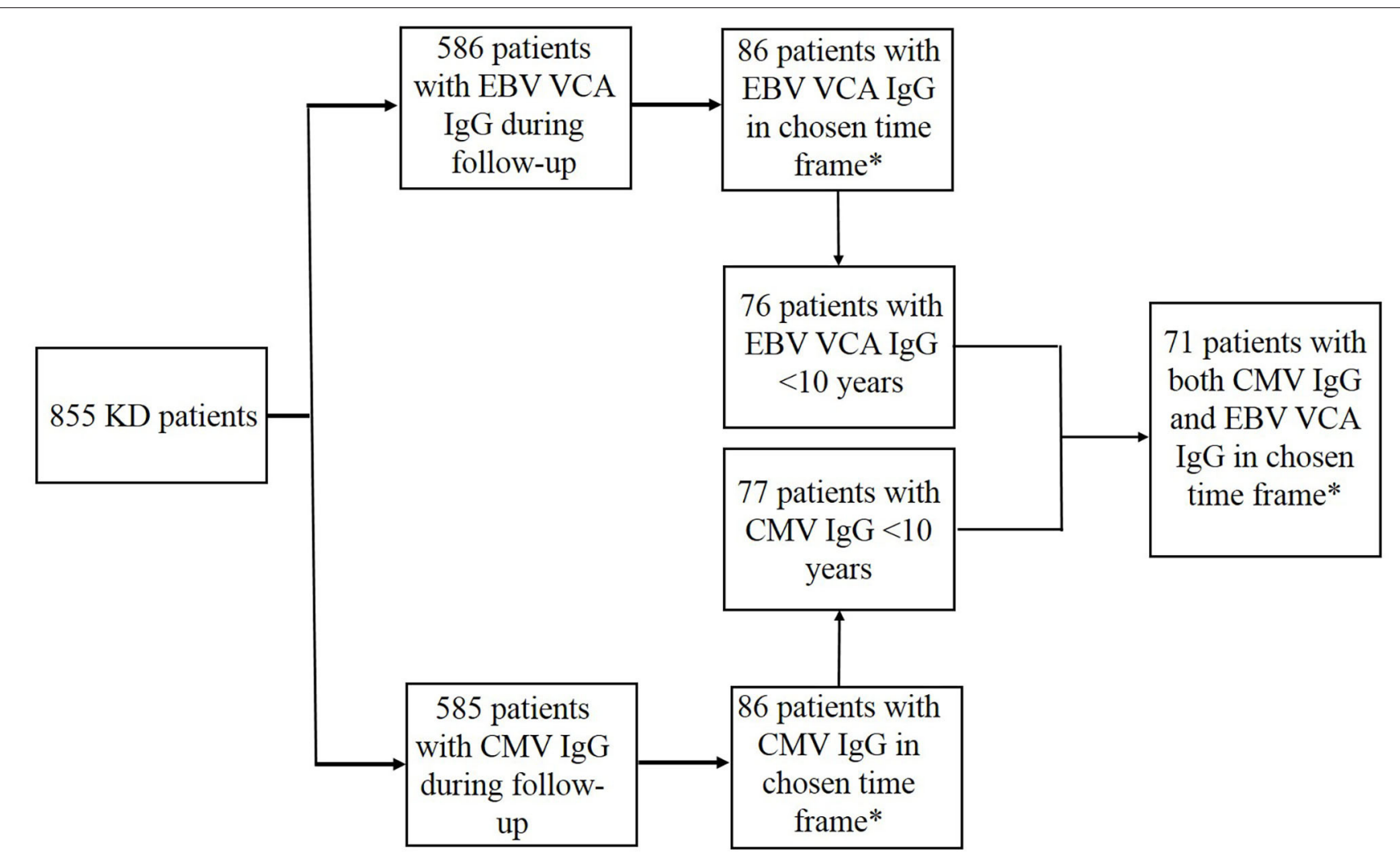

FIGURE 1 | Patient selection. *Chosen time frame was 9 months after IVIG treatment but not later than 2 years after onset of disease.

EBV might have a protective role in the susceptibility to $\mathrm{KD}$ at young age.

In the past, low exposure to infectious agents in early childhood has been proposed to increase the susceptibility to allergic diseases and autoimmune diseases due to the influence on the development of the immune system (66). Allergic reactions are known to be initiated by $\mathrm{T}$ helper lymphocytes while in $\mathrm{KD}$ a cellular immune dysfunction i.a. the imbalance of Th1 and Th2 or "split T cell anergy" has been suggested $(67,68)$. The theories about hygiene or the under-challenged immune system due to low exposure to environmental or infectious agents, have been suggested to contribute to a pathological response to a pathogen (69), which may be relevant to triggering $\mathrm{KD}$ in genetically susceptible children. Several studies have shown an increase of allergies in $\mathrm{KD}$ patients compared to the general population, which may support a link between hygiene and environmental conditions involved in the slow but progressive rise in $\mathrm{KD}$ incidence worldwide which can be neither caused by improved recognition and diagnostic skills of doctors nor by current laboratory tests for KD since these are not yet applicable (70-73).

An under-challenged immune system has previously been reported to have a causal connection to pre-dispose children to specific diseases such as Acute Lymphoblastic Leukemia (60, $61,64)$. However, the majority of these studies used daycare attendance as an indicator for exposure to common infections, which is a very indirect measurement. Reasoning that at young age a viral infection could be such a trigger knowing that in the past several viral infections have been suggested as the cause of KD (49-54), we used CMV and EBV IgG seropositivity as an indication for exposure to common infections in this study. By excluding IgM positive results, we excluded the possibility of cross-reactive antibody results, which are a possible confounding factor if you look at an acute infection of these two viruses. Once infected, herpes viruses such as CMV and EBV stay lifelong present and do not cause any symptoms in healthy individuals, being suppressed by the immune system $(63,74$, 75). Viral reactivation of herpes viruses may sometimes occur, especially during moments of reduced T-cell mediated immune suppression by concurrent disease such as malignancy, chronic disease, or the use of immunosuppressive medication, which then causes a raised alertness of the immune system against these viruses to keep them constrained. If immunity cannot suppress these reactivated viruses, the reactivated viruses may result in clinical disease. We have not observed any clinical reactivation as indicated by shingles or herpes zoster by herpes simplex virus (HSV) or varicella-zoster virus (VZV), respectively, or EBV or CMV DNA plasma concentrations during acute KD, indicating a globally intact immunity in these children.

When measuring seroprevalence of EBV and CMV, we observed a significant difference for EBV VCA IgG exposure in the KD group compared to the control group, except for the very young age category of $0.5-2$ years old. The lack of significance 
TABLE 2 | Characteristics KD population.

\begin{tabular}{|c|c|c|c|c|c|c|}
\hline & \multicolumn{2}{|c|}{ CMV IgG tested } & \multicolumn{2}{|c|}{ EBV VCA IgG tested } & \multicolumn{2}{|c|}{$\begin{array}{c}\text { Both EBV VCA IgG and CMV IgG tested on the } \\
\text { same date }\end{array}$} \\
\hline & $n$ (total $=86$ ) & $\%$ & $n$ (total $=86$ ) & $\%$ & $n$ (total $=77$ ) & $\%$ \\
\hline \multicolumn{7}{|c|}{ IVIG treatment } \\
\hline $0.5-2$ years & $12(15)$ & 80.0 & $12(14)$ & 85.7 & $10(12)$ & 83.3 \\
\hline $2-4$ years & $25(28)$ & 89.2 & $26(29)$ & 89.7 & $25(27)$ & 92.6 \\
\hline $4-6$ years & $15(19)$ & 78.9 & $13(17)$ & 76.5 & $13(17)$ & 76.5 \\
\hline $6-10$ years & $12(15)$ & 80.0 & $12(16)$ & 75.0 & $12(15)$ & 80.0 \\
\hline $10-18$ years & $6(9)$ & 66.7 & $8(10)$ & 80.0 & $5(6)$ & 83.3 \\
\hline \multicolumn{7}{|l|}{ Male gender } \\
\hline $0.5-2$ years & $10(15)$ & 66.7 & $9(14)$ & 64.3 & $8(12)$ & 66.7 \\
\hline $2-4$ years & $18(28)$ & 64.3 & $19(29)$ & 65.5 & $17(27)$ & 63.0 \\
\hline $4-6$ years & $14(19)$ & 73.7 & $13(17)$ & 76.5 & $13(17)$ & 76.5 \\
\hline $6-10$ years & $8(15)$ & 53.3 & $9(16)$ & 56.3 & $8(15)$ & 53.3 \\
\hline 10-18 years & 7 (9) & 77.8 & $9(10)$ & 90.0 & $6(6)$ & 100 \\
\hline \multicolumn{7}{|c|}{ Complete KD* } \\
\hline $0.5-2$ years & $8(15)$ & 53.3 & $8(14)$ & 57.1 & $6(12)$ & 50.0 \\
\hline $2-4$ years & $22(28)$ & 78.6 & $21(29)$ & 72.4 & $21(27)$ & 77.8 \\
\hline $4-6$ years & $14(19)$ & 73.7 & $13(17)$ & 76.5 & $13(17)$ & 76.5 \\
\hline $6-10$ years & $12(15)$ & 80.0 & $13(16)$ & 81.3 & $13(15)$ & 86.7 \\
\hline $10-18$ years & $6(9)$ & 66.7 & $9(10)$ & 90.0 & $5(6)$ & 83.3 \\
\hline \multicolumn{7}{|c|}{ No enlargement of coronary artery in acute phase $(Z \text { score }<2.5)^{\star \star}$} \\
\hline $0.5-2$ years & $10(15)$ & 66.7 & $9(14)$ & 64.3 & $6(12)$ & 50.0 \\
\hline $2-4$ years & $19(28)$ & 67.9 & $20(29)$ & 68.9 & $18(27)$ & 66.7 \\
\hline $4-6$ years & $14(19)$ & 73.7 & $12(17)$ & 70.5 & $12(17)$ & 70.6 \\
\hline $6-10$ years & $11(15)$ & 73.3 & $12(16)$ & 75.0 & $11(15)$ & 73.3 \\
\hline $10-18$ years & $5(9)$ & 55.6 & $6(10)$ & 60.0 & $4(6)$ & 66.7 \\
\hline \multicolumn{7}{|c|}{ Enlargement of coronary artery in acute phase $(Z \text { score } 2.5-10)^{\star *}$} \\
\hline $0.5-2$ years & $3(15)$ & 20.0 & $3(14)$ & 21.4 & $3(12)$ & 25.0 \\
\hline $2-4$ years & $2(28)$ & 7.1 & $2(29)$ & 10.5 & $2(27)$ & 7.4 \\
\hline $4-6$ years & $3(19)$ & 15.8 & $3(17)$ & 17.6 & $3(17)$ & 17.6 \\
\hline $6-10$ years & $1(15)$ & 6.7 & $1(16)$ & 6.25 & $1(15)$ & 6.7 \\
\hline $10-18$ years & $1(9)$ & 11.1 & $1(10)$ & 10.0 & $1(6)$ & 16.7 \\
\hline \multicolumn{7}{|c|}{ Giant aneurysm in acute phase $(Z \text { score } \geq 10)^{\star *}$} \\
\hline $0.5-2$ years & $2(15)$ & 13.3 & $2(14)$ & 14.3 & $2(12)$ & 16.7 \\
\hline $2-4$ years & $4(28)$ & 14.3 & $4(29)$ & 13.8 & $4(27)$ & 14.8 \\
\hline $4-6$ years & $1(19)$ & 5.3 & $1(17)$ & 5.9 & $1(17)$ & 5.9 \\
\hline $6-10$ years & $0(15)$ & 0 & $0(16)$ & 0 & $0(15)$ & 0 \\
\hline $10-18$ years & $0(9)$ & 0 & $0(10)$ & 0 & $0(6)$ & 0 \\
\hline \multicolumn{7}{|c|}{ Dutch ethnicity ${ }^{\star \star \star}$ (both parents) } \\
\hline $0.5-2$ years & $7(15)$ & 46.7 & $6(14)$ & 42.9 & $4(12)$ & 33.3 \\
\hline $2-4$ years & $13(28)$ & 46.4 & $13(29)$ & 44.8 & $13(27)$ & 48.1 \\
\hline $4-6$ years & $8(19)$ & 42.1 & $8(17)$ & 47.1 & $8(17)$ & 47.1 \\
\hline $6-10$ years & $7(15)$ & 46.7 & $8(16)$ & 50.0 & $7(15)$ & 46.7 \\
\hline $10-18$ years & $6(9)$ & 66.7 & $7(10)$ & 70.0 & $4(6)$ & 66.7 \\
\hline \multicolumn{7}{|c|}{ 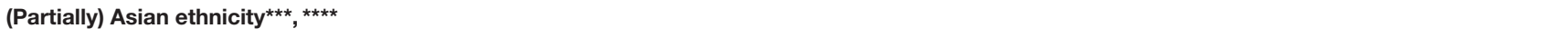 } \\
\hline $0.5-2$ years & $0(15)$ & 0 & $0(14)$ & 0 & $0(12)$ & 0 \\
\hline $2-4$ years & $3(28)$ & 10.7 & $3(29)$ & 10.3 & $3(27)$ & 11.1 \\
\hline $4-6$ years & $2(19)$ & 10.5 & $2(17)$ & 11.8 & $2(17)$ & 11.8 \\
\hline $6-10$ years & $2(15)$ & 13.3 & $2(16)$ & 12.5 & $2(15)$ & 13.3 \\
\hline 10-18 years & $0(9)$ & 0 & $0(10)$ & 0 & $0(6)$ & 0 \\
\hline
\end{tabular}


TABLE 2 | Continued

\begin{tabular}{|c|c|c|c|c|c|c|}
\hline & \multicolumn{2}{|c|}{ CMV IgG tested } & \multicolumn{2}{|c|}{ EBV VCA IgG tested } & \multicolumn{2}{|c|}{$\begin{array}{l}\text { Both EBV VCA IgG and CMV IgG tested on the } \\
\text { same date }\end{array}$} \\
\hline & $n$ (total $=86$ ) & $\%$ & $n$ (total $=86$ ) & $\%$ & $n$ (total $=77$ ) & $\%$ \\
\hline \multicolumn{7}{|c|}{ Other or unknown ethnicity ${ }^{\star \star \star}$} \\
\hline $0.5-2$ years & $8(15)$ & 53.3 & $8(14)$ & 57.1 & $8(12)$ & 66.7 \\
\hline $2-4$ years & $12(28)$ & 42.9 & $13(29)$ & 44.8 & $11(27)$ & 40.7 \\
\hline $4-6$ years & $9(19)$ & 47.4 & $7(17)$ & 41.2 & $7(17)$ & 41.2 \\
\hline $6-10$ years & $6(15)$ & 40.0 & $6(16)$ & 37.5 & $6(15)$ & 40.0 \\
\hline 10-18 years & 3 (9) & 33.3 & $3(10)$ & 30.0 & $2(6)$ & 33.3 \\
\hline \multicolumn{7}{|c|}{$\begin{array}{l}{ }^{*} \text { Complete } K D \text { is defined as: fever, combined with a minimum of four of the five other symptor } \\
\text { mouth). In } 4 \text { patients the symptoms were unknown. } \\
{ }^{* \star Z} Z \text { score was calculated using the McCrindle/Boston model. } \\
{ }^{\star \star \star} \text { Ethnicities were reported by parents/care-givers. } \\
{ }^{\star \star \star \star A} \text { Asian countries that were included were: Vietnam, Japan, China, Indonesia and Thailand. }\end{array}$} \\
\hline & & \multicolumn{4}{|c|}{$\begin{array}{l}\Delta \text { Time CMV IgG } \\
\text { (median, range) in months }\end{array}$} & $\begin{array}{l}\Delta \text { Time EBV VCA IgG } \\
\text { (median, range) in months }\end{array}$ \\
\hline $0.5-2$ years & & \multicolumn{4}{|c|}{$14(12-17), n=8$} & $14(12-16), n=9$ \\
\hline Patients with & at diagnosis, prior & \multicolumn{4}{|c|}{$n=4$} & $n=3$ \\
\hline Patients that & IVIG & \multicolumn{3}{|c|}{$n=3$} & & $n=2$ \\
\hline $2-4$ years & & \multicolumn{3}{|c|}{$15(10-22), n=21$} & & 15 (10-22), $n=21$ \\
\hline Patients with & at diagnosis, prior & \multicolumn{3}{|c|}{$n=4$} & & $n=5$ \\
\hline Patients that & IVIG & \multicolumn{3}{|c|}{$n=3$} & & $n=3$ \\
\hline 4-6 years & & \multicolumn{3}{|c|}{$14(10-23), n=13$} & & $14(10-23), n=12$ \\
\hline Patients with & at diagnosis, prior & \multicolumn{3}{|c|}{$n=3$} & & $n=2$ \\
\hline Patients that & IVIG & \multicolumn{3}{|c|}{$n=3$} & & $n=3$ \\
\hline $6-10$ years & & \multicolumn{3}{|c|}{$13(10-22), n=11$} & & $14.5(10-22), n=12$ \\
\hline Patients with & at diagnosis, prior & \multicolumn{3}{|c|}{$n=1$} & & $n=1$ \\
\hline Patients that & IVIG & \multicolumn{3}{|c|}{$n=3$} & & $n=3$ \\
\hline
\end{tabular}

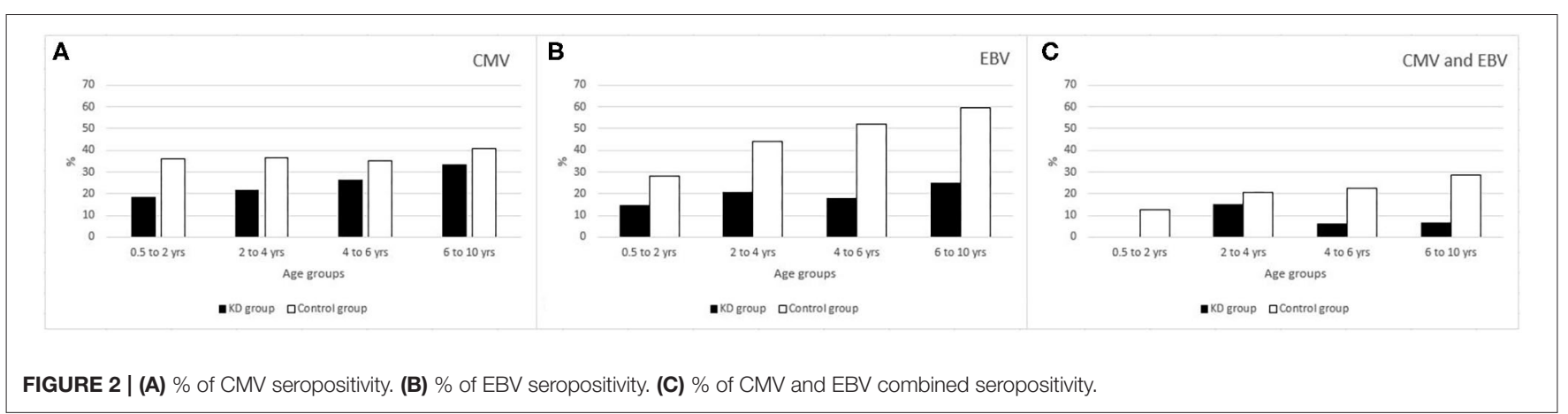

could be explained by a generally low exposure to EBV in this age group and hence an underpowered comparison. In the same age group of $0.5-2$ years old, there was a noticeable difference for CMV IgG seropositivity, which could be explained by higher contagiousness of CMV in early childhood and unnoticed transmission by breastfeeding, which may transmit CMV but far less commonly EBV (76-82). The differences in seroprevalance between EBV and CMV seem to decrease as age increases in our KD cohort. Of the positive EBV anti-VCA IgG measurements a few had anti-EBNA measurements $(n=12)$. Anti-EBNA antibodies are usually undetectable during the (sub)acute phase of the infection and slowly appear after onset of disease within the following weeks or months. Therefore, a positive anti-EBNA response indicates an infection in the past. From the anti-EBNA 
measurements most were negative $(67 \%)$, with a median time of 14.5 months (range 11-18 months) between IVIG infusion and date of measurement. These infections could therefore be more recent, possibly after $\mathrm{KD}$. But caution needs to be taken with the interpretation of anti-EBNA measurements due to the wide range in which even healthy controls can become positive. Of the cases in which both anti-EBNA and anti-VCA IgG were positive, the median time between IVIG and date of measurement was 14.5 months (range 11-18 months). We did not assess the anti-EBNA measurements in the control group due to the before mentioned limited value of these EBNA antibodies (83). The possibility of spurious IgG seropositive measurements because of prior IVIG infusion $(65,84)$ was excluded because of the time passed [14 months (range 0-23)] between the administration of IVIG and the measurement of the actual serology.

$\mathrm{CMV}$ is known to challenge the immune system, altering the immune response to other pathogens (85). Both EBV and CMV cause a redistribution in B-cell subsets (86-88). Herpes viruses like EBV and CMV causing systemic infection of the immune system and the lifelong survival within the host with transient virus reactivation from time to time-going most often completely unnoticed and without any clinical symptoms (74, 89-96) -, are expected to leave an imprint on the immune system because of their lifelong infection of that same system. This effect on the host's immune system could affect the response to a pathogen, also to the as yet unidentified and probably miscellaneous agents that may trigger $\mathrm{KD}$. Although we cannot directly prove the hypothesis, our findings may suggest that insufficient priming of the immune system at an early age plays a role in the immune response in $\mathrm{KD}$. Although we do not want to overemphasize a direct role in $\mathrm{KD}$ susceptibility for the two herpesviruses that we have tested, the rising incidence of $\mathrm{KD}$ in Japan, and the falling incidence of EBV at the same time (97) would support this theory on an under-challenged immune system. At the molecular level the immunological data currently available on epigenetic imprinting of $\mathrm{T}$ and $\mathrm{B}$ lymphocytes also indicate that previous infections impact the reactivity against subsequent triggers. These phenomena are definitely not considered as $\mathrm{KD}$-specific or selective for certain age categories, but it supports the notion that prior exposure shapes the immunological outcome. Similar findings have been demonstrated at the epigenetic level of the innate immune system by exposure to mycobacterial components, which more recently has been a basis for BCG immunization to protect from SarsCoV2 infection, as an example of "trained (innate) immunity" (98). The induction of a mature and experienced immune system to protect from a wide variety of triggers at young age may help to understand the otherwise unexplained incidence of $\mathrm{KD}$ in the under- 5 years old while becoming almost zero at late adolescence $(99,100)$.

This is a study with intrinsic limitations, namely our control group might not be a representation of a completely healthy population due to the fact that the serological tests were requested by general practitioners and doctors from the hospital for
KD-unrelated reasons. On the other hand, these anonymous controls were screened for infection similar to the children presenting with $\mathrm{KD}$, for that reason being a cohort that might be more comparable with our KD children than a completely healthy population.

\section{CONCLUSION}

We observed a significantly reduced CMV and EBV prevalence in $\mathrm{KD}$ patients compared to age-matched controls. The data suggest that an under-challenged immune system may contribute to the inflammatory vasculitis in children with an inherent polygenic and complex susceptibility to KD.

\section{DATA AVAILABILITY STATEMENT}

The original contributions generated in the study are included in the article/supplementary material, further inquiries can be directed to the corresponding author.

\section{ETHICS STATEMENT}

Ethical review and approval was not required for the study on human participants in accordance with the local legislation and institutional requirements. Written informed consent to participate in this study was provided by the participants' legal guardian/next of kin.

\section{AUTHOR CONTRIBUTIONS}

DS conceptualized the study, collected data, interpreted data, and drafted the manuscript. AS collected data, performed the analysis, and contributed in the initial draft of the manuscript. TK and $\mathrm{HZ}$ coordinated and supervised data collection and reviewed the manuscript for important intellectual content and revised the manuscript. All authors approved the final manuscript as submitted and agree to be accountable for all aspects of the work.

\section{FUNDING}

Funding was made available by the foundation Kind en Handicap and an anonymous donor through the AMC foundation.

\section{ACKNOWLEDGMENTS}

We gratefully thank the Kawasaki disease Study Group: M. Bruijn, L. Delemarre, K. Dolman, L. Filippini, T. Hendriks, M. Felderhof, J. Noordzij, R. Nuboer, F. B. Plötz, L. Rozendaal, J. J. Verhoeven, A. Vlieger, N. Weggelaar, and P. de Winter for their contribution to this article by referring patients from their clinics to our tertiary center for the follow-up. The authors also sincerely acknowledge I. M. Kuipers, pediatric cardiologist of the Kawasaki disease Study Group, for her contribution to the treatment and monitoring during follow-up of patients. 


\section{REFERENCES}

1. van Stijn-Bringas Dimitriades D, Planken RN, Groenink M, Streekstra GJ, Kuijpers TW, Kuipers IM. Coronary artery assessment in Kawasaki disease with dual-source CT angiography to uncover vascular pathology. Eur Radiol. (2019). doi: 10.1007/s00330-019-06367-6

2. McCrindle BW, Manlhiot C, Newburger JW, Harahsheh AS, Giglia TM, Dallaire F, et al. Medium-term complications associated with coronary artery aneurysms after kawasaki disease: a study from the international kawasaki disease registry. J Am Heart Assoc. (2020) 9:e016440. doi: 10.1161/jaha.119.016440

3. Furusho K, Kamiya T, Nakano H, Kiyosawa N, Shinomiya K, Hayashidera T, et al. High-dose intravenous gammaglobulin for Kawasaki disease. Lancet. (1984) 2:1055-8. doi: 10.1016/S0140-6736(84)91504-6

4. Terai M, Shulman ST. Prevalence of coronary artery abnormalities in Kawasaki disease is highly dependent on gamma globulin dose but independent of salicylate dose. J Pediatr. (1997) 131:888-93. doi: 10.1016/S0022-3476(97)70038-6

5. Kuwabara M, Yashiro M, Ae R, Yanagawa H, Nakamura Y. The effects of early intravenous immunoglobulin therapy for Kawasaki disease: the 22nd nationwide survey in Japan. Int J Cardiol. (2018) 269:334-8. doi: 10.1016/j.ijcard.2018.07.092

6. Shiozawa Y, Inuzuka R, Shindo T, Mafune R, Hayashi T, Hirata Y, et al. Effect of i.v. immunoglobulin in the first 4 days of illness in Kawasaki disease. Pediatr Int. (2018) 60:334-41. doi: 10.1111/ped.13512

7. Downie ML, Manlhiot C, Collins TH, Chahal N, Yeung RSM, McCrindle BW. Factors associated with development of coronary artery aneurysms after Kawasaki disease are similar for those treated promptly and those with delayed or no treatment. Int J Cardiol. (2017) 236:157-61. doi: 10.1016/j.ijcard.2017.01.068

8. Salgado AP, Ashouri N, Berry EK, Sun X, Jain S, Burns JC, et al. High risk of coronary artery aneurysms in infants younger than 6 months of age with Kawasaki disease. J Pediatr. (2017) 185:112-6.e1. doi: 10.1016/j.jpeds.2017.03.025

9. Liu MY, Liu HM, Wu CH, Chang CH, Huang GJ, Chen CA, et al. Risk factors and implications of progressive coronary dilatation in children with Kawasaki disease. BMC Pediatr. (2017) 17:139. doi: 10.1186/s12887-017-0895-8

10. Callinan LS, Tabnak F, Holman RC, Maddox RA, Kim JJ, Schonberger LB, et al. Kawasaki syndrome and factors associated with coronary artery abnormalities in California. Pediatr Infect Dis J. (2012) 31:894-8. doi: 10.1097/INF.0b013e31825c4d7c

11. Tacke CE, Breunis WB, Pereira RR, Breur JM, Kuipers IM, Kuijpers TW. Five years of Kawasaki disease in the Netherlands: a national surveillance study. Pediatr Infect Dis J. (2014) 33:793-7. doi: 10.1097/INF.0000000000000271

12. Newburger JW, Takahashi M, Gerber MA, Gewitz MH, Tani LY, Burns JC, et al. Diagnosis, treatment, and long-term management of Kawasaki disease: a statement for health professionals from the Committee on Rheumatic Fever, Endocarditis and Kawasaki Disease, Council on Cardiovascular Disease in the Young, American Heart Association. Circulation. (2004) 110:2747-71. doi: 10.1161/01.CIR.0000145143.19711.78

13. Hara T, Nakashima Y, Sakai Y, Nishio H, Motomura Y, Yamasaki S. Kawasaki disease: a matter of innate immunity. Clin Exp Immunol. (2016) 186:134-43. doi: $10.1111 /$ cei.12832

14. Rowley AH, Shulman ST. The epidemiology and pathogenesis of Kawasaki disease. Front Pediatr. (2018) 6:374. doi: 10.3389/fped.2018.00374

15. Brown TJ, Crawford SE, Cornwall ML, Garcia F, Shulman ST, Rowley AH. CD8 T lymphocytes and macrophages infiltrate coronary artery aneurysms in acute Kawasaki disease. J Infect Dis. (2001) 184:940-3. doi: 10.1086/323155

16. Onouchi Y, Ozaki K, Buns JC, Shimizu C, Hamada H, Honda T, et al. Common variants in CASP3 confer susceptibility to Kawasaki disease. Hum Mol Genet. (2010) 19:2898-906. doi: 10.1093/hmg/ddq176

17. Onouchi Y. The genetics of Kawasaki disease. Int J Rheum Dis. (2018) 21:26-30. doi: 10.1111/1756-185X.13218

18. Tsujimoto H, Takeshita S, Nakatani K, Kawamura Y, Tokutomi T, Sekine I. Delayed apoptosis of circulating neutrophils in Kawasaki disease. Clin Exp Immunol. (2001) 126:355-64. doi: 10.1046/j.1365-2249.2001. 01675.x
19. Yeter D, Deth R. ITPKC susceptibility in Kawasaki syndrome as a sensitizing factor for autoimmunity and coronary arterial wall relaxation induced by thimerosal's effects on calcium signaling via IP3. Autoimmun Rev. (2012) 11:903-8. doi: 10.1016/j.autrev.2012.03.006

20. Onouchi Y, Suzuki Y, Suzuki H, Terai M, Yasukawa K, Hamada H, et al. ITPKC and CASP3 polymorphisms and risks for IVIG unresponsiveness and coronary artery lesion formation in Kawasaki disease. Pharmacogenomics J. (2013) 13:52-9. doi: 10.1038/tpj.2011.45

21. Onouchi Y, Gunji T, Burns JC, Shimizu C, Newburger JW, Yashiro M, et al. ITPKC functional polymorphism associated with Kawasaki disease susceptibility and formation of coronary artery aneurysms. Nat Genet. (2008) 40:35-42. doi: 10.1038/ng.2007.59

22. Lou J, Xu S, Zou L, Zhong R, Zhang T, Sun Y, et al. A functional polymorphism, rs28493229, in ITPKC and risk of Kawasaki disease: an integrated meta-analysis. Mol Biol Rep. (2012) 39:11137-44. doi: 10.1007/s11033-012-2022-0

23. Onouchi Y, Onoue S, Tamari M, Wakui K, Fukushima Y, Yashiro M, et al. CD40 ligand gene and Kawasaki disease. Eur J Hum Genet. (2004) 12:1062-8. doi: 10.1038/sj.ejhg.5201266

24. Lou J, Zhong R, Shen N, Lu XZ, Ke JT, Duan JY, et al. Systematic confirmation study of GWAS-identified genetic variants for Kawasaki disease in a Chinese population. Sci Rep. (2015) 5:8194. doi: 10.1038/srep08194

25. Lee YC, Kuo HC, Chang JS, Chang LY, Huang LM, Chen MR, et al. Two new susceptibility loci for Kawasaki disease identified through genome-wide association analysis. Nat Genet. (2012) 44:522-5. doi: 10.1038/ng.2227

26. Huang FY, Chang TY, Chen MR, Chiu NC, Chi H, Lee HC, et al. Genetic polymorphisms in the CD40 ligand gene and Kawasaki disease. J Clin Immunol. (2008) 28:405-10. doi: 10.1007/s10875-008-9203-6

27. Biezeveld M, Geissler J, Merkus M, Kuipers IM, Ottenkamp J, Kuijpers $\mathrm{T}$. The involvement of $\mathrm{Fc}$ gamma receptor gene polymorphisms in Kawasaki disease. Clin Exp Immunol. (2007) 147:106-11. doi: 10.1111/j.1365-2249.2006.03266.x

28. Duan J, Lou J, Zhang Q, Ke J, Qi Y, Shen N, et al. A genetic variant rs1801274 in FCGR2A as a potential risk marker for Kawasaki disease: a case-control study and meta-analysis. PLoS ONE. (2014) 9:e103329. doi: 10.1371/journal.pone.0103329

29. Khor CC, Davila S, Breunis WB, Lee YC, Shimizu C, Wright VJ, et al. Genome-wide association study identifies FCGR2A as a susceptibility locus for Kawasaki disease. Nat Genet. (2011) 43:1241-6. doi: 10.1038/ng.981

30. Kuo HC, Chang JC, Kuo HC, Yu HR, Wang CL, Lee CP, et al. Identification of an association between genomic hypomethylation of FCGR2A and susceptibility to Kawasaki disease and intravenous immunoglobulin resistance by DNA methylation array. Arthritis Rheumatol (Hoboken, NJ). (2015) 67:828-36. doi: 10.1002/art.38976

31. Kuo HC, Chao MC, Hsu YW, Lin YC, Huang YH, Yu HR, et al. CD40 Gene polymorphisms associated with susceptibility and coronary artery lesions of Kawasaki disease in the Taiwanese population. Sci World J. (2012) 2012:520865. doi: 10.1100/2012/520865

32. Kuo HC, Hsu YW, Wu CM, Chen SH, Hung KS, Chang WP, et al. A replication study for association of ITPKC and CASP3 two-locus analysis in IVIG unresponsiveness and coronary artery lesion in Kawasaki disease. PLoS ONE. (2013) 8:e69685. doi: 10.1371/journal.pone.0069685

33. Kuo HC, Hsu YW, Lo MH, Huang YH, Chien SC, Chang WC. Single-nucleotide polymorphism rs7251246 in ITPKC is associated with susceptibility and coronary artery lesions in Kawasaki disease. PLoS ONE. (2014) 9:e91118. doi: 10.1371/journal.pone.0091118

34. Wang CL, Wu YT, Liu CA, Lin MW, Lee CJ, Huang LT, et al. Expression of CD40 ligand on CD4+ T-cells and platelets correlated to the coronary artery lesion and disease progress in Kawasaki disease. Pediatrics. (2003) 111:E140-7. doi: 10.1542/peds.111.2.e140

35. Shendre A, Wiener HW, Zhi D, Vazquez AI, Portman MA, Shrestha S. High-density genotyping of immune loci in Kawasaki disease and IVIG treatment response in European-American case-parent trio study. Genes Immun. (2014) 15:534-42. doi: 10.1038/gene.2014.47

36. Shrestha S, Wiener HW, Olson AK, Edberg JC, Bowles NE, Patel H, et al. Functional FCGR2B gene variants influence intravenous immunoglobulin response in patients with Kawasaki disease. J Allergy Clin Immunol. (2011) 128:677-80. doi: 10.1016/j.jaci.2011.04.027 
37. Shrestha S, Wiener H, Shendre A, Kaslow RA, Wu J, Olson A, et al. Role of activating FcgammaR gene polymorphisms in Kawasaki disease susceptibility and intravenous immunoglobulin response. Circ Cardiovasc Genet. (2012) 5:309-16. doi: 10.1161/CIRCGENETICS.111.962464

38. Makowsky R, Wiener HW, Ptacek TS, Silva M, Shendre A, Edberg JC, et al. FcgammaR gene copy number in Kawasaki disease and intravenous immunoglobulin treatment response. Pharmacogenet Genomics. (2013) 23:455-62. doi: 10.1097/FPC.0b013e328363686e

39. Kuo HC, Hsu YW, Wu MS, Woon PY, Wong HS, Tsai LJ, et al. FCGR2A promoter methylation and risks for intravenous immunoglobulin treatment responses in Kawasaki disease. Mediat Inflamm. (2015) 2015:564625. doi: $10.1155 / 2015 / 564625$

40. Chang LS, Lo MH, Li SC, Yang MY, Hsieh KS, Kuo HC. The effect of FcgammaRIIA and FcgammaRIIB on coronary artery lesion formation and intravenous immunoglobulin treatment responses in children with Kawasaki disease. Oncotarget. (2016) 8:2044-52. doi: 10.18632/oncotarget.13489

41. Rowley AH, Eckerley CA, Jack HM, Shulman ST, Baker SC. IgA plasma cells in vascular tissue of patients with Kawasaki syndrome. J Immunol (Baltimore, Md: 1950). (1997) 159:5946-55.

42. Rowley AH, Shulman ST. Kawasaki syndrome. Pediatr Clin North Am. (1999) 46:313-29. doi: 10.1016/S0031-3955(05)70120-6

43. Burns JC, Cayan DR, Tong G, Bainto EV, Turner CL, Shike H, et al. Seasonality and temporal clustering of Kawasaki syndrome. Epidemiology. (2005) 16:220-5. doi: 10.1097/01.ede.0000152901.06689.d4

44. Nakamura Y, Yashiro M, Uehara R, Sadakane A, Tsuboi S, Aoyama $\mathrm{Y}$, et al. Epidemiologic features of Kawasaki disease in Japan: results of the 2009-2010 nationwide survey. J Epidemiol. (2012) 22:216-21. doi: 10.2188/jea.JE20110126

45. Verdoni L, Mazza A, Gervasoni A, Martelli L, Ruggeri M, Ciuffreda M, et al. An outbreak of severe Kawasaki-like disease at the Italian epicentre of the SARS-CoV-2 epidemic: an observational cohort study. Lancet. (2020) 395:1771-8. doi: 10.1016/S0140-6736(20)31103-X

46. Kanegaye JT, Wilder MS, Molkara D, Frazer JR, Pancheri J, Tremoulet AH, et al. Recognition of a Kawasaki disease shock syndrome. Pediatrics. (2009) 123:e783-9. doi: 10.1542/peds.2008-1871

47. Tissandier C, Lang M, Lusson JR, Bœuf B, Merlin E, Dauphin C. Kawasaki shock syndrome complicating a recurrence of Kawasaki disease. Pediatrics. (2014) 134:e1695-9. doi: 10.1542/peds.2014-0004

48. Gamez-Gonzalez LB, Moribe-Quintero I, Cisneros-Castolo M, Varela-Ortiz J, Munoz-Ramirez M, Garrido-Garcia M, et al. Kawasaki disease shock syndrome: unique and severe subtype of Kawasaki disease. Pediatr Int. (2018) 60:781-90. doi: 10.1111/ped.13614

49. Ouldali N, Pouletty M, Mariani P, Beyler C, Blachier A, Bonacorsi S, et al. Emergence of Kawasaki disease related to SARS-CoV-2 infection in an epicentre of the French COVID-19 epidemic: a time-series analysis. Lancet Child Adolesc Health. (2020) 4:662-8. doi: 10.1016/S2352-4642(20)30175-9

50. Viner RM, Whittaker E. Kawasaki-like disease: emerging complication during the COVID-19 pandemic. Lancet. (2020) 395:1741-3. doi: 10.1016/S0140-6736(20)31129-6

51. Schulz TF, Hoad JG, Whitby D, Tizard EJ, Dillon MJ, Weiss RA. A measles virus isolate from a child with Kawasaki disease: sequence comparison with contemporaneous isolates from 'classical' cases. J Gen Virol. (1992) 73:1581-6. doi: 10.1099/0022-1317-73-6-1581

52. Hagiwara K, Yoshida T, Komura H, Kishi F, Kajii T. Isolation of human herpesvirus-6 from an infant with Kawasaki disease. Eur J Pediatr. (1993) 152:176. doi: 10.1007/BF02072502

53. Nigro G, Zerbini M, Krzysztofiak A, Gentilomi G, Porcaro MA, Mango $\mathrm{T}$, et al. Active or recent parvovirus B19 infection in children with Kawasaki disease. Lancet. (1994) 343:1260-1. doi: 10.1016/S0140-6736(94) 92154-7

54. Kikuta H, Sakiyama Y, Matsumoto S, Hamada I, Yazaki M, Iwaki $\mathrm{T}$, et al. Detection of Epstein-Barr virus DNA in cardiac and aortic tissues from chronic, active Epstein-Barr virus infection associated with Kawasaki disease-like coronary artery aneurysms. J Pediatr. (1993) 123:90-2. doi: 10.1016/S0022-3476(05)81546-X

55. Riphagen S, Gomez X, Gonzalez-Martinez C, Wilkinson N, Theocharis P. Hyperinflammatory shock in children during COVID-19 pandemic. Lancet. (2020) 395:1607-8. doi: 10.1016/S0140-6736(20)31094-1
56. Rowley AH, Shulman ST, Mask CA, Finn LS, Terai M, Baker SC, et al. IgA plasma cell infiltration of proximal respiratory tract, pancreas, kidney, and coronary artery in acute Kawasaki disease. J Infect Dis. (2000) 182:1183-91. doi: $10.1086 / 315832$

57. Rowley AH, Shulman ST, Spike BT, Mask CA, Baker SC. Oligoclonal IgA response in the vascular wall in acute Kawasaki disease. J Immunol (Baltimore, Md: 1950). (2001) 166:1334-43. doi: 10.4049/jimmunol.166.2.1334

58. Rodo X, Ballester J, Cayan D, Melish ME, Nakamura Y, Uehara R, et al. Association of Kawasaki disease with tropospheric wind patterns. Sci Rep. (2011) 1:152. doi: 10.1038/srep00152

59. Rodo X, Curcoll R, Robinson M, Ballester J, Burns JC, Cayan DR, et al. Tropospheric winds from northeastern China carry the etiologic agent of Kawasaki disease from its source to Japan. Proc Natl Acad Sci USA. (2014) 111:7952-7. doi: 10.1073/pnas.1400380111

60. Ma X, Buffler PA, Selvin S, Matthay KK, Wiencke JK, Wiemels JL, et al. Daycare attendance and risk of childhood acute lymphoblastic leukaemia. Br J Cancer. (2002) 86:1419-24. doi: 10.1038/sj.bjc.6600274

61. Greaves MF. Aetiology of acute leukaemia. Lancet. (1997) 349:344-9. doi: 10.1016/S0140-6736(96)09412-3

62. Roman E, Simpson J, Ansell P, Kinsey S, Mitchell CD, McKinney PA, et al. Childhood acute lymphoblastic leukemia and infections in the first year of life: a report from the United Kingdom Childhood Cancer Study. Am J Epidemiol. (2007) 165:496-504. doi: 10.1093/aje/kwk039

63. Evans AS. Epidemiological concepts and methods. In: Evans AS, editor. Viral Infections of Humans: Epidemiology and Control. Boston, MA: Springer (1976). p. 1-32.

64. McCrindle BW, Rowley AH, Newburger JW, Burns JC, Bolger AF, Gewitz $M$, et al. Diagnosis, treatment, and long-term management of kawasaki disease: a scientific statement for health professionals from the American Heart Association. Circulation. (2017) 135:e927-99. doi: 10.1161/CIR.0000000000000484

65. Tacke CE, Smits GP, van der Klis FR, Kuipers IM, Zaaijer HL, Kuijpers TW. Reduced serologic response to mumps, measles, and rubella vaccination in patients treated with intravenous immunoglobulin for Kawasaki disease. $J$ Allergy Clin Immunol. (2013) 131:1701-3. doi: 10.1016/j.jaci.2013.01.045

66. Okada H, Kuhn C, Feillet H, Bach JF. The 'hygiene hypothesis' for autoimmune and allergic diseases: an update. Clin Exp Immunol. (2010) 160:1-9. doi: 10.1111/j.1365-2249.2010.04139.x

67. Matsubara T, Katayama K, Matsuoka T, Fujiwara M, Koga M, Furukawa S. Decreased interferon-gamma (IFN-gamma)-producing $\mathrm{T}$ cells in patients with acute Kawasaki disease. Clin Exp Immunol. (1999) 116:554-7. doi: 10.1046/j.1365-2249.1999.00899.x

68. Kuijpers TW, Wiegman A, van Lier RA, Roos MT, Wertheim-van Dillen PM, Pinedo S, et al. Kawasaki disease: a maturational defect in immune responsiveness. J Infect Dis. (1999) 180:1869-77. doi: 10.1086/315111

69. Burgner D, Harnden A. Kawasaki disease: what is the epidemiology telling us about the etiology? Int J Infect Dis. (2005) 9:185-94. doi: 10.1016/j.ijid.2005.03.002

70. Liew WK, Lim CW, Tan TH, Wong KY, Tai BC, Quek SC, et al. The effect of Kawasaki disease on childhood allergies-a sibling control study. Pediatr Allergy Immunol. (2011) 22:488-93. doi: 10.1111/j.1399-3038.2011.01149.x

71. Matsuoka S, Tatara K, Nakagawa R, Mori K, Kuroda Y. Tendency toward atopy in Kawasaki disease. Eur J Pediatr. (1997) 156:30-2. doi: 10.1007/s004310050546

72. Zandstra J, van de Geer A, Tanck MWT, van Stijn-Bringas Dimitriades D, Aarts CEM, Dietz SM, et al. Biomarkers for the discrimination of acute Kawasaki disease from infections in childhood. Front Pediatr. (2020) 8:355. doi: 10.3389/fped.2020.00355

73. Wright VJ, Herberg JA, Kaforou M, Shimizu C, Eleftherohorinou H, Shailes $\mathrm{H}$, et al. Diagnosis of Kawasaki disease using a minimal wholeblood gene expression signature. JAMA Pediatr. (2018) 172:e182293. doi: 10.1001/jamapediatrics.2018.2293

74. Taylor GS, Long HM, Brooks JM, Rickinson AB, Hislop AD. The immunology of Epstein-Barr virus-induced disease. Annu Rev Immunol. (2015) 33:787-821. doi: 10.1146/annurev-immunol-032414-112326

75. Young LS, Rickinson AB. Epstein-Barr virus: 40 years on. Nat Rev Cancer. (2004) 4:757-68. doi: 10.1038/nrc1452 
76. Bardanzellu F, Fanos V, Reali A. Human breast milk-acquired cytomegalovirus infection: certainties, doubts and perspectives. Curr Pediatr Rev. (2019) 15:30-41. doi: 10.2174/1573396315666181126105812

77. Junker AK, Thomas EE, Radcliffe A, Forsyth RB, Davidson AG, Rymo L. Epstein-Barr virus shedding in breast milk. Am J Med Sci. (1991) 302:220-3. doi: 10.1097/00000441-199110000-00005

78. Kusuhara K, Takabayashi A, Ueda K, Hidaka Y, Minamishima I, Take H, et al. Breast milk is not a significant source for early Epstein-Barr virus or human herpesvirus 6 infection in infants: a seroepidemiologic study in 2 endemic areas of human T-cell lymphotropic virus type I in Japan. Microbiol Immunol. (1997) 41:309-12. doi: 10.1111/j.1348-0421.1997.tb01206.x

79. Viljoen J, Tuaillon E, Nagot N, Danaviah S, Peries M, Padayachee P, et al. Cytomegalovirus, and possibly Epstein-Barr virus, shedding in breast milk is associated with HIV-1 transmission by breastfeeding. Aids. (2015) 29:14553. doi: 10.1097/QAD.0000000000000527

80. Sanosyan A, Rutagwera DG, Molès JP, Bollore K, Peries M, Kankasa C, et al. Increased Epstein-Barr virus in breast milk occurs with subclinical mastitis and HIV shedding. Medicine (Baltimore). (2016) 95:e4005. doi: 10.1097/MD.0000000000004005

81. Glenn WK, Whitaker NJ, Lawson JS. High risk human papillomavirus and Epstein Barr virus in human breast milk. BMC Res Notes. (2012) 5:477. doi: 10.1186/1756-0500-5-477

82. Daud, II, Coleman CB, Smith NA, Ogolla S, Simbiri K, Bukusi EA, et al. Breast milk as a potential source of Epstein-Barr virus transmission among infants living in a malaria-endemic region of Kenya. J Infect Dis. (2015) 212:1735-42. doi: 10.1093/infdis/jiv290

83. Chan KH, Ng MH, Seto WH, Peiris JS. Epstein-Barr virus (EBV) DNA in sera of patients with primary EBV infection. J Clin Microbiol. (2001) 39:4152-4. doi: 10.1128/JCM.39.11.4152-4154;2001

84. Miura M, Katada Y, Ishihara J. Time interval of measles vaccination in patients with Kawasaki disease treated with additional intravenous immune globulin. Eur J Pediatr. (2004) 163:25-9. doi: 10.1007/s00431-003-1335-3

85. Reddehase MJ. Adverse immunological imprinting by cytomegalovirus sensitizing for allergic airway disease. Med Microbiol Immunol. (2019) 208:469-73. doi: 10.1007/s00430-019-00610-Z

86. Lasaviciute G, Bjorkander S, Carvalho-Queiroz C, Hed Myrberg I, Nussbaum B, Nilsson C, et al. Epstein-Barr Virus, but not cytomegalovirus, latency accelerates the decay of childhood measles and rubella vaccine responses-a 10-year follow-up of a Swedish birth cohort. Front Immunol. (2017) 8:1865. doi: 10.3389/fimmu.2017. 01865

87. Schmidl C, Delacher M, Huehn J, Feuerer M. Epigenetic mechanisms regulating T-cell responses. J Allergy Clin Immunol. (2018) 142:728-43. doi: 10.1016/j.jaci.2018.07.014

88. Zhang Y, Good-Jacobson KL. Epigenetic regulation of B cell fate and function during an immune response. Immunol Rev. (2019) 288:75-84. doi: 10.1111/imr.12733

89. Maurmann S, Fricke L, Wagner HJ, Schlenke P, Hennig H, Steinhoff J, et al. Molecular parameters for precise diagnosis of asymptomatic Epstein-Barr virus reactivation in healthy carriers. $J$ Clin Microbiol. (2003) 41:5419-28. doi: 10.1128/JCM.41.12.5419-5428. 2003
90. Jayasooriya S, de Silva TI, Njie-jobe J, Sanyang C, Leese AM, Bell AI, et al. Early virological and immunological events in asymptomatic EpsteinBarr virus infection in African children. PLoS Pathog. (2015) 11:e1004746. doi: 10.1371/journal.ppat.1004746

91. Abbott RJ, Pachnio A, Pedroza-Pacheco I, Leese AM, Begum J, Long $\mathrm{HM}$, et al. Asymptomatic primary infection with Epstein-Barr Virus: observations on young adult cases. J Virol. (2017) 91:e00382-17. doi: 10.1128/JVI.00382-17

92. Rostgaard K, Balfour HH, Jr., Jarrett R, Erikstrup C, Pedersen $\mathrm{O}$, Ullum $\mathrm{H}$, et al. Primary Epstein-Barr virus infection with and without infectious mononucleosis. PLoS ONE. (2019) 14:e0226436. doi: 10.1371/journal.pone.0226436

93. Zanghellini F, Boppana SB, Emery VC, Griffiths PD, Pass RF. Asymptomatic primary cytomegalovirus infection: virologic and immunologic features. J Infect Dis. (1999) 180:702-7. doi: 10.1086/ 314939

94. Ahlfors K, Ivarsson SA, Johnsson T, Svensson I. Congenital and acquired cytomegalovirus infections. Virological and clinical studies on a Swedish infant population. Acta Paediatr Scand. (1978) 67:321-8. doi: 10.1111/j.1651-2227.1978.tb16328.x

95. Griffiths PD, Baboonian C. A prospective study of primary cytomegalovirus infection during pregnancy: final report. Br J Obstet Gynaecol. (1984) 91:30715. doi: 10.1111/j.1471-0528.1984.tb05915.x

96. Stagno S, Pass RF, Cloud G, Britt WJ, Henderson RE, Walton PD, et al. Primary cytomegalovirus infection in pregnancy. Incidence, transmission to fetus, and clinical outcome. JAMA. (1986) 256:1904-8. doi: 10.1001/jama.1986.03380140074025

97. Takeuchi K, Tanaka-Taya K, Kazuyama Y, Ito YM, Hashimoto $S$, Fukayama $M$, et al. Prevalence of Epstein-Barr virus in Japan: trends and future prediction. Pathol Int. (2006) 56:112-6. doi: $10.1111 / \mathrm{j} .1440-1827.2006 .01936 . x$

98. Curtis N, Sparrow A, Ghebreyesus TA, Netea MG. Considering BCG vaccination to reduce the impact of COVID-19. Lancet. (2020) 395:1545-6. doi: 10.1016/S0140-6736(20)31025-4

99. Hall GC, Tulloh LE, Tulloh RM. Kawasaki disease incidence in children and adolescents: an observational study in primary care. Br J Gen Pract. (2016) 66:e271-6. doi: 10.3399/bjgp16X684325

100. Kitano N, Suzuki H, Takeuchi T. Patient age and the seasonal pattern of onset of Kawasaki's disease. N Engl J Med. (2018) 378:2048-9. doi: 10.1056/NEJMc1804312

Conflict of Interest: The authors declare that the research was conducted in the absence of any commercial or financial relationships that could be construed as a potential conflict of interest.

Copyright (c) 2021 van Stijn, Slegers, Zaaijer and Kuijpers. This is an open-access article distributed under the terms of the Creative Commons Attribution License (CC $B Y)$. The use, distribution or reproduction in other forums is permitted, provided the original author(s) and the copyright owner(s) are credited and that the original publication in this journal is cited, in accordance with accepted academic practice. No use, distribution or reproduction is permitted which does not comply with these terms. 